\title{
A Systematic Mapping Study of Software Usability Studies
}

\author{
Abdulwahab Ali Almazroi \\ University of Jeddah, College of Computing and Information Technology at Khulais \\ Department of Information Technology, Jeddah, Saudi Arabia
}

\begin{abstract}
Among software quality attributes "software usability" is considered as one of the vital factors in software engineering literature. Software usability is the ability for users to generally understand, use, and learn a software with ease. Due to the importance of usability in software quality, a considerable amount of literature is published in the past decade. Few review and survey studies are also published to critically review the existing literature in the domain. However, there is limited research covering systematic mapping study of software usability. Mapping studies help in analyzing the general trends and research productivity in a research area. To fill this gap, this work critically examines the overall research productivity, demographics, trends, and challenges of software usability. The objective is to classify the current contributions and trends in the area of software usability. We retrieved 9,874 research articles from six research databases and 62 works are selected as primary studies using an evidence-based approach. The result of this mapping study shows that software usability is an active research area, with a promising number of works published in the last decade $(2011$ - 2020). We identified that the current literature spans over multiple article classes of which investigative papers, model proposals and evaluation papers are the most frequently published article types. We found experiments and theoretical validations to be the most common validation techniques. In terms of application domains; web, software development and mobile applications are the most frequent domains where usability studies are conducted. We identified that future usability studies should focus more on field studies as well as on the usability testing of scientific software packages. It will be of importance to consider ethical issues in usability testing as well.
\end{abstract}

Keywords-Software usability; usability study; systematic mapping study; systematic literature review; software engineering

\section{INTRODUCTION}

Based on IEEE Std.610.12, software usability is the user's simplicity in learning to provide inputs and operate a given component or system [1]. Although software and system usability are considered as non-functional requirements, its importance cannot be overstated [2]. Sagar and Saha [3] listed six software quality criteria which includes usability as well. As modern-day software is evolving to be more complex and omnipresent, software usability has become an indispensable non-functional requirement for ensuring software quality.

In the field of software engineering, various studies have identified usability issues and its implication on software quality [4-6]. As per ISO/IEC 9126, software usability is the ability of users to generally understand, use, and learn the software with ease. Based on [7], there are five important usability attributes, which are learnability, attractiveness, understandability, operability, and usability compliance. Thus, the definition for software usability differs among different standards and researchers [3].

In the real world, various application domains have duly considered usability engineering as an important area. It is widely considered to be a far-reaching research area at large [3] and is used in domains such as aerospace [8], computer-based medical devices [9], defense[10], mobile devices [11], web applications [12] etc. Various research and review studies were conducted on software usability [3, 11-21]. However, based on our findings from the existing literature, we observed that a systematic mapping study (SMS) in this domain is lacking, confirming the claim of Bitkina, et al. [9] regarding the absence of UX/usability studies. Hence, this SMS is undertaken to fill this research gap through the extensive analysis of important studies that were published in the last decade (2011-2020). Filling this research gap will help researchers and experts better understand software usability's efficiency, effectiveness, and development.

In an effort to fill the research gap and inclusion of significant works, this research followed systematic mapping methodology. This approach allows the research to capture key facts and details from literature using a well-defined process. To this end, an SMS protocol composed of search strategy, data extraction, selection criteria, and rejection criteria was formed. The main objective of this research is to investigate factors affecting software usability. Additionally, this researched also aimed at classifying the selected studies by knowing the existing contributions, research facets conducted, validation methods used, evaluation measures utilized, application domains, and lastly the overall demographics of the literature reviewed. The selected parameters will provide an overview of the general trends of the publications as well as the evolution of research in the domain of software usability.

In this study, the main contributions are as follows:

- A detailed examination and synthesis of key studies on software usability.

- The study reviews primary studies (PS) and identify their distinct contributions.

- The mapping study analyzes the overall research productivity, demographics, trends, and challenges in software usability. 
- The research identifies area of research that are least addressed and provides directions for future research.

This research study is divided into six sections. Section II presents various aspects of software usability and discusses related surveys in the domain of software usability. Section III describes the research methodology including research questions, data acquisition and processing techniques. Results are presented in Section IV. Section V discusses the research findings as well as directions for future research, whereas threats to validity are discussed in Section VI. Section VII concludes the work.

\section{SOFTWARE USABILITY AND RELATED WORK}

This section discusses software usability by reviewing articles published in the area.

\section{A. Software Usability}

Software usability is a key characteristic of software quality. As per ISO/IEC 9126, usability is defined as "a set of attributes that bear on the effort needed for use, and on the individual assessment of such use, by a stated or implied set of users" [3, 7]. Based on [7], software quality model is composed of six dimensions, which are functionality, portability, maintainability, efficiency, usability and reliability.

However, usability is inconsistently defined in the literature, where different standards and researchers have distinct definitions. In the following text, some definitions of software usability from various standards are outlined. In a study by Nielsen, the author defined usability based on five key dimensions. These dimensions are efficiency, errors, learnability, memorability, and satisfaction [22]. Efficiency means that the system should be efficient to be utilized by a user. When the system is efficiently utilized, productivity will increase. It is also expected that such systems have low error rates. Learnability is the ability to understand the system, and a good system is expected to have small learning curve. Memorability refers to the ability of the system to be easily remembered without requiring users to relearn things again. Lastly, satisfaction means that the user should feel gratified when using the system. Moreover, in the ISO 9241-11, usability is defined as the level where a product can be utilized by a given user in achieving a specific objective with efficiency, effectiveness, and satisfaction in a defined context $[23,24]$.

In software engineering, usability issues in software directly or indirectly contribute to software quality problems. These problems often cause low efficiency and effectiveness. Based on this, users encounter various difficulties when using a specific software [25]. Further, the usability issues can also lead to low acceptance rate of software applications [26].

\section{B. Related Work}

This section summarizes the existing literature in software usability and identifies the research gaps.

Bastien [27] focused on the growing applications of Information and Communication Technology (ICT) based medical devices incorporating human-computer interfaces. The author highlighted that usability of these medical devices' hinges on their ease of usability. The author identified inspection-, user- and model-based evaluations as standard industry approaches for validating usability. The work considered various scenarios and provided directions for further research in usability testing for mobile applications. Usability testing can be performed in a number of manners such as questionnaires, interviews, automated testing etc. Sure [21] considered questionnaire as a method for usability testing where information about usability, user satisfaction, expectations, software behavior and other related information is collected using a set of questions. The author identified thirteen questionnaires from literature. The analysis of the questionnaires revealed that 'satisfaction' is the most common factor that is measured by the majority of the questionnaires.

Esmeria and Seva [18] presented a survey of works in relation to the usability of the websites. The authors argued that the process of usability testing should result in a usability index that can describe the usability of a website. A drawback of the work is the lack of rigor in selection of data sources. The authors relied on Science Direct and ACM Digital Library only and no specific query string was mentioned. Sagar and Saha [3] conducted a review of the software usability and reached to a variety of conclusions. The authors identified that so far researchers have not been able to unanimously agree on usability models. Further, the work highlighted efficiency, effectiveness, satisfaction, and learnability as standard measures used by a majority of the usability models. In terms of usability evaluation methods, questionnaires, usability testing and heuristic evaluations are the leading mechanisms.

Maramba et al. [28] conducted a systematic review of usability testing of e-health applications. The authors observed that although there is an exponential increase in the development and subsequence deployment of e-health applications, very few of these applications have published their usability evaluation results. The work further highlighted that questionnaire has been the de-facto method for usability analysis and argued that more qualitative and automated methods must be used in usability evaluation. Key limitations of the work include the limited time frame for the selection of potential works (April 2014 - October 2017) and the scope of the work which is limited to e-health applications only. Weichbroth [29] used Scopus as data source to conduct a systematic literature review of usability aspects of mobile applications. The author identified 790 relevant documents spanning 2001 to 2018 . It was observed that the usability definition as given in ISO 9241-11 is used by majority of the works. The work identified 75 attributes associated with the usability of mobile applications and identified efficiency, satisfaction and effectiveness as most important considerations as indicated in the literature. Memorability, cognitive load and errors are identified as least considered attributes. Like Maramba, et al. [28], and Weichbroth [29] observed that controlled observations and surveys are mostly used in usability studies and suggested the use of eye-tracking, thinking loud, and interviews to be used in the future usability studies. Besides these studies, other important works include Coursaris and Kim [30], Harrison, et al. [31], and Quiñones and Rusu [32]. 
TABLE I. SUMMARY OF THE SELECTED SURVEYS

\begin{tabular}{|c|c|c|c|c|c|}
\hline S. No & $\begin{array}{l}\text { Study and } \\
\text { Year }\end{array}$ & Selected Databases & Keywords & $\begin{array}{l}\text { No. of } \\
\text { Selected } \\
\text { Articles }\end{array}$ & Limitations \\
\hline 1 & $\begin{array}{l}\text { Harrison, et al. } \\
\text { [31] (2013) }\end{array}$ & $\begin{array}{l}\text { ACM Digital Library, Google } \\
\text { Scholar, IEEE Xplore }\end{array}$ & $\begin{array}{l}\text { Mobile application evaluations, } \\
\text { mobile application usability } \\
\text { evaluations, usability of mobile } \\
\text { applications }\end{array}$ & 131 & $\begin{array}{l}\text { Narrow scope focusing on mobile } \\
\text { applications only } \\
\text { Unavailability of } 6 \% \text { of the selected } \\
\text { papers }\end{array}$ \\
\hline 2 & $\begin{array}{l}\text { Sure }[21] \\
(2014)\end{array}$ & ACM Digital Library, Inspec & $\begin{array}{l}\text { Usability, Questionnaire, } \\
\text { Reliability, Validity }\end{array}$ & 35 & $\begin{array}{l}\text { Generic query terms } \\
\text { Use of Inspec and ACM Digital library } \\
\text { for literature search } \\
\text { Limited scope focusing on questionnaires } \\
\text { for a usability study }\end{array}$ \\
\hline 3 & $\begin{array}{l}\text { Esmeria and } \\
\text { Seva [18] } \\
(2017)\end{array}$ & $\begin{array}{l}\text { ACM Digital Library, } \\
\text { ScienceDirect }\end{array}$ & $\begin{array}{l}\text { Website usability evaluation, } \\
\text { measures of web usability }\end{array}$ & 42 & $\begin{array}{l}\text { Lack of rigor in selection of data sources } \\
\text { Reliance on ACM Digital Library and } \\
\text { Science Direct only }\end{array}$ \\
\hline 4 & $\begin{array}{l}\text { Quiñones and } \\
\text { Rusu [32] } \\
\text { (2017). }\end{array}$ & $\begin{array}{l}\text { ACM Digital Library, Science } \\
\text { Direct, IEEE Xplore, Springer } \\
\text { Link, Scopus, Google Scholar }\end{array}$ & $\begin{array}{l}\text { Usability heuristic(s), } \\
\text { methodology, heuristic } \\
\text { evaluation, formal process, } \\
\text { usability design }\end{array}$ & 73 & Focused on usability heuristics only \\
\hline 5 & $\begin{array}{l}\text { Maramba, et al. } \\
\text { [28] (2019) }\end{array}$ & $\begin{array}{l}\text { ACM Digital Library, } \\
\text { CINAHL, IEEE Xplore, } \\
\text { Medline / PubMed. }\end{array}$ & eHealth, mHealth, usability & 133 & $\begin{array}{l}\text { Limited focus on e-health applications } \\
\text { only } \\
\text { Very short time frame selection }\end{array}$ \\
\hline 6 & $\begin{array}{l}\text { Weichbroth } \\
\text { [29] (2020) }\end{array}$ & Scopus & Usability, mobile applications & 66 & $\begin{array}{l}\text { A narrow focus on mobile applications } \\
\text { Use of single source for data collection }\end{array}$ \\
\hline
\end{tabular}

Table I presents a summary of the selected related works. Note that some works such as Bastien [27] and Coursaris and Kim [30] are not included in the table as these works did not use the standard methodology for conducting systematic literature review.

Despite the usefulness of these studies, none of the highlighted studies in this section conducted a systematic mapping study for software usability. Most papers study selection process is also arbitrary with no rigor or repeatability. Hence, we observed that there is no study in the software usability that categorize and analyze existing research with respect to their research facets, contribution facets, publication forums/trends, citation impacts, and so on. Thus, the aim of this research is to fill these gaps in the field.

\section{Methodology}

Systematic mapping studies (SMS) are conducted to provide a general overview of a research area by systematically classifying the existing works and identify the contributions of researchers in the area of study. The studies (SMS) largely explore current literature to examine the reporting of areas, publication frequency, research trends, and publication venues where the primary studies are published [33, 34]. There are many shared characteristics between a systematic literature review (SLR) and systematic mapping studies. Some of the characteristics are the use of evidence-based searching and study selection procedures. However, SMS has a distinct objective from SLR and took a different approach to data analysis. SMS is primarily aimed at mapping and structuring an area of study. Hence, in this study, the SMS follows the general guidelines suggested by Petersen, et al. [34] and Kitchenham and Brereton [35]. Consequently, this study follows the pathway of similar studies that adopt these guidelines [36-38]. Fig. 1 outlines the process for our study.

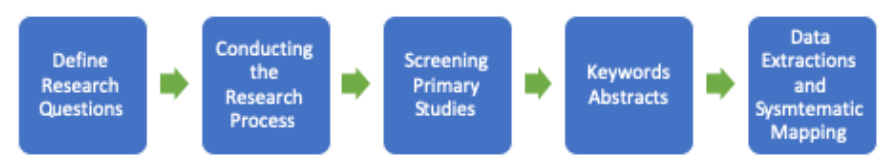

Fig. 1. The Systematic Mapping Process.

As depicted in Fig. 1, the SMS process comprises of five distinct stages. The initial stage is to define key research questions (RQs). In stage two, the search process is conducted by specifying the search terms for retrieving the primary studies (PS). In the third and fourth stages, the retrieved studies are screened to remove unnecessary and irrelevant studies. Lastly, the data extraction is conducted, and the systematic maps of the study are created. These stages are defined in the following text.

\section{A. Research Questions}

In this section, the research questions (RQs) of the study are presented with respect to our main research objective. The main objective of this SMS is to classify the selected studies by knowing the existing contributions, research facets, validation methods, evaluation measures, application domains, and the overall demographics of the selected studies. The key question of this SMS is "what is the state-of-the-art in software usability studies?". Based on the objective of the work, the key question is divided into six distinct RQs as presented in Table II.

\section{B. Data Sources}

A SMS heavily relies on the selected Primary Studies (PS). To achieve a good mapping, it is vital that the process of selecting the PS is conducted carefully. The literature on software usability was collected from 2011 to 2020. Six data sources were selected for our literature search. The data sources include ACM Digital Library, IEEE Xplore, Google Scholar, Science Direct, SpringerLink, and Taylor and Francis. 
It is important to mention that the selected sources include most the publications in the area of usability. Scopus could not be included as the author was unable to obtain access to the restricted (subscription based) database of Scopus. However, the selected six sources for data retrieval are broad and comprehensive enough to provide coverage to most of the reputable publications' outlets. In addition, the selected sources are used in other studies such as Esmeria and Seva [18] and Maramba, et al. [28]. Table III highlights the data sources with respect to the studies identified in our initial result search. The initial search resulted in 9,874 studies, out of which 62 studies were shortlisted based selection criteria covered in Section 3.D.

TABLE II. THE DEFINED RESEARCH QUESTIONS

\begin{tabular}{|l|l|l|}
\hline RQ\# & Research Question & Motivation \\
\hline RQ1 & $\begin{array}{l}\text { What are the demographic } \\
\text { characteristics of the PS? }\end{array}$ & $\begin{array}{l}\text { To identify publication trend, } \\
\text { publication forums and citation } \\
\text { impact of the primary studies. }\end{array}$ \\
\hline RQ2 & $\begin{array}{l}\text { What contribution facets have } \\
\text { the primary studies provided? }\end{array}$ & $\begin{array}{l}\text { To identify the contribution } \\
\text { facets (model, method, } \\
\text { investigation, and so on). }\end{array}$ \\
\hline RQ3 & $\begin{array}{l}\text { What are the research types } \\
\text { facet) focused on by the } \\
\text { primary studies in the domain? }\end{array}$ & $\begin{array}{l}\text { To ascertain the research facets } \\
\text { (evaluation research, solution } \\
\text { proposal, and so on) in the area } \\
\text { of study. }\end{array}$ \\
\hline RQ4 & $\begin{array}{l}\text { What validation methods are } \\
\text { generally utilized for software } \\
\text { usability evaluation? }\end{array}$ & $\begin{array}{l}\text { To identify various software } \\
\text { usability evaluation methods. }\end{array}$ \\
\hline RQ5 & $\begin{array}{l}\text { What are the various application } \\
\text { domains for usability? }\end{array}$ & $\begin{array}{l}\text { To investigate the domains of } \\
\text { application for usability. }\end{array}$ \\
\hline RQ6 & $\begin{array}{l}\text { What are the evaluation } \\
\text { measures used by the PS? }\end{array}$ & $\begin{array}{l}\text { To identify the evaluation } \\
\text { measures used by the selected } \\
\text { studies. }\end{array}$ \\
\hline
\end{tabular}

TABLE III. STUDIES IDENTIFIED IN EACH DATA SOURCES

\begin{tabular}{|c|c|c|c|}
\hline \multicolumn{2}{|c|}{ Data Source } & \multirow{2}{*}{$\begin{array}{l}\text { Initial Results of } \\
\text { Search }\end{array}$} & \multirow{2}{*}{$\begin{array}{l}\text { Final Selected } \\
\text { Studies }\end{array}$} \\
\hline$I D$ & Name & & \\
\hline D1 & IEEE Xplore & 729 & 18 \\
\hline D2 & Science Direct & 1,208 & 15 \\
\hline D3 & Taylor and Francis & 76 & 12 \\
\hline D4 & ACM & 957 & 7 \\
\hline D5 & SpringerLink & 467 & 5 \\
\hline D6 & Google Scholar & 6,437 & 5 \\
\hline \multicolumn{2}{|c|}{ Total } & 9,874 & 62 \\
\hline
\end{tabular}

\section{Search Terms}

We performed automatic searches to retrieve important studies from our selected data sources. This is achieved using our search string or terms developed based on the guidelines of Petersen, et al. [34]. Basically, a search string is a composition of characters used by a researcher to identify the most relevant set of documents from a data source. Therefore, selecting the right search string is imperative because the outcome is connected to the information given by the data source. Hence, the selection of right terms requires careful attention to ensure important studies are not missed in the mapping process. In doing so, a generic search string was formulated to work on all the data sources. The search string is outlined as follows.

((Software usability AND Usability models) OR (Usability metrics))

It is important to point out that the search term is relatively generic to ensure that maximum results are obtained. A carefully crafted inclusion and exclusion criterion is then applied to shortlist the publications for further study. After execution of the search terms on respective data sources, the resultant publications obtained from each of the data source are reflected in Table III. A total of 9,874 publications were retrieved. Note that the search query was executed to collect the raw data from 19 November 2020 to 25 December 2020.

\section{Inclusion and Exclusion Criterion}

When the search results utilizing the articulated search string are acquired, we anticipated that works that are not important to the objective of this SMS study can also be retrieved. If so happens, we cautiously designed a clear inclusion and exclusion criteria that will be used on the retrieved studies to eliminate those that are not in-line with the objective of the paper. The inclusion-exclusion criteria for this study are outlined as follows;

Inclusion Criteria:

- Include studies on software usability

- Include studies that were published in the past 10 years $(2011$ - 2020)

- Include only peer-reviewed studies

Exclusion Criteria:

- $\quad$ Exclude survey and review studies

- Short Papers

- $\quad$ Editorials

- Summaries of keynotes

- Exclude the studies that are not on software usability

- Exclude the studies that are not written in English

After a careful implementation of inclusion and exclusion criterion, and thorough manual analysis including removal of duplicates, we identified 62 primary studies for further analysis.

\section{E. Extraction of Data}

To extract data from each of the 62 primary studies for answering the formulated RQs, a systematic data extraction method has to be clearly defined. We created a form to extract important data from the 62 identified articles for this study. The author as well as the two volunteers filled out the form for each of the 62 selected papers. For each publication, title, publication venue, research type, contributions, validation method, publication year, evaluation measures and application domain were recorded. 


\section{F. Classification Scheme}

We followed Petersen, et al. [34] to develop the classification scheme for this study. The 62 final selected studies were examined by their titles, abstracts, keywords, research contributions, theoretical models, and general demographics. These studies were comprehensively studied for a thorough understanding of various characteristics of the classification. The first step is to classify the PS into the contributions made by various researchers. These contributions are investigative study, evaluation study, model, framework, application, scheme, method, usability concepts, usability principles, approach, and system. We further extended the classification to identify the research facets. These facets are experience papers, evaluation research, solution proposals, and validation research. These classifications are standard and in line with the existing literature for conducting a mapping study $[34,38]$. Subsequently, further classifications of the PS were done with respect to the validation methods used to validate software usability, evaluation measures, application domains, and the selected studies general demographic characteristics.

\section{REsUlts}

This section covers the results of the research. The RQs formulated are all answered by critically analyzing the PS studies. Table IV presents the PS for this study. For the sake of brevity, only research article IDs is provided. For mapping between IDs and research articles description, the reader is referred to Appendix A.

TABLE IV. OVERVIEW OF SELECTED STUDIES

\begin{tabular}{|l|l|l|l|l|}
\hline $\begin{array}{l}\text { PS } \\
\text { Paper } \\
\text { ID }\end{array}$ & $\begin{array}{l}\text { Year of } \\
\text { Publication }\end{array}$ & $\begin{array}{l}\text { Publication } \\
\text { Channel }\end{array}$ & $\begin{array}{l}\text { Citation } \\
\text { Count }\end{array}$ & Contribution \\
\hline B1 & 2020 & IEEE & 2 & Approach \\
\hline B2 & 2017 & ACM & 5 & Model \\
\hline B3 & 2017 & ACM & 2 & Model \\
\hline B4 & 2019 & ACM & 0 & Evaluation \\
\hline B5 & 2020 & Springer & 1 & Evaluation \\
\hline B6 & 2019 & Springer & 1 & Metrics \\
\hline B7 & 2017 & IEEE & 4 & Evaluation \\
\hline B8 & 2017 & IEEE & 1 & Evaluation \\
\hline B9 & 2017 & IEEE & 3 & Investigation \\
\hline B10 & 2018 & ACM & 2 & Investigation \\
\hline B11 & 2018 & IEEE & 0 & Investigation \\
\hline B12 & 2018 & IEEE & 1 & Method \\
\hline B13 & 2016 & Taylor and Francis & 13 & $\begin{array}{l}\text { Usability } \\
\text { concepts }\end{array}$ \\
\hline B14 & 2015 & Taylor and Francis & 62 & Investigation \\
\hline B15 & 2016 & Taylor and Francis & 10 & Investigation \\
\hline B16 & 2016 & Taylor and Francis & 3 & Evaluation \\
\hline B17 & 2015 & Taylor and Francis & 42 & Investigation \\
\hline B18 & 2011 & Elsevier & 92 & Investigation \\
\hline B19 & 2013 & Taylor and Francis & 78 & $\begin{array}{l}\text { Usability } \\
\text { principles }\end{array}$ \\
\hline B20 & 2016 & Taylor and Francis & 2 & Investigation \\
\hline
\end{tabular}

\begin{tabular}{|c|c|c|c|c|}
\hline B21 & 2012 & Elsevier & 284 & Investigation \\
\hline B22 & 2013 & IEEE & 78 & $\begin{array}{l}\text { Usability } \\
\text { guidelines }\end{array}$ \\
\hline B23 & 2011 & Elsevier & 74 & Evaluation \\
\hline B24 & 2012 & Elsevier & 75 & Investigation \\
\hline B25 & 2013 & Elsevier & 63 & Investigation \\
\hline B26 & 2011 & $\mathrm{ACM}$ & 17 & Model \\
\hline B27 & 2020 & IEEE & 0 & Evaluation \\
\hline B28 & 2020 & IEEE & 1 & Investigation \\
\hline B29 & 2011 & Independent & 60 & Investigation \\
\hline B30 & 2013 & Springer & 23 & Evaluation \\
\hline B31 & 2016 & Springer & 103 & Evaluation \\
\hline B32 & 2014 & Independent & 113 & Evaluation \\
\hline B33 & 2019 & IEEE & 1 & Evaluation \\
\hline B34 & 2019 & IEEE & 0 & Investigation \\
\hline B35 & 2018 & IEEE & 0 & Model \\
\hline B36 & 2018 & IEEE & 1 & Investigation \\
\hline B37 & 2019 & IEEE & 1 & Model \\
\hline B38 & 2013 & Elsevier & 66 & Framework \\
\hline B39 & 2019 & IEEE & 4 & System \\
\hline B40 & 2014 & Elsevier & 24 & Scheme \\
\hline B41 & 2020 & IEEE & 0 & Investigation \\
\hline B42 & 2015 & Independent & 1 & Approach \\
\hline B43 & 2019 & IEEE & 0 & Investigation \\
\hline B44 & 2014 & Elsevier & 34 & Evaluation \\
\hline B45 & 2015 & Taylor and Francis & 4 & Investigation \\
\hline B46 & 2015 & Taylor and Francis & 118 & Evaluation \\
\hline B47 & 2012 & Elsevier & 25 & Application \\
\hline B48 & 2015 & Elsevier & 20 & Model \\
\hline B49 & 2012 & Taylor and Francis & 83 & Evaluation \\
\hline B50 & 2013 & Springer & 12 & Evaluation \\
\hline B51 & 2012 & $\mathrm{ACM}$ & 20 & Investigation \\
\hline B52 & 2013 & Taylor and Francis & 14 & Investigation \\
\hline B53 & 2013 & IEEE & 1 & Model \\
\hline B54 & 2011 & $\mathrm{ACM}$ & 8 & Evaluation \\
\hline B55 & 2013 & Taylor and Francis & 33 & Evaluation \\
\hline B56 & 2015 & Elsevier & 15 & Application \\
\hline B57 & 2013 & Independent & 3 & Model \\
\hline B58 & 2015 & Elsevier & 29 & Investigation \\
\hline B59 & 2013 & Elsevier & 8 & Investigation \\
\hline B60 & 2015 & Elsevier & 21 & Approach \\
\hline B61 & 2013 & Elsevier & 47 & Evaluation \\
\hline B62 & 2011 & Independent & 1 & Investigation \\
\hline
\end{tabular}

A. RQ1. What are the Demographics Characteristics of the PS?

In answering this RQ, the primary studies were analyzed critically with the purpose of answering the RQ. Three aspects of the PS were analyzed including publication trend, publication forums, and citation impact. 
Publication trend: From 2011 to 2020, 62 studies were retrieved from the data sources. In Fig. 2, the year-wise publications in the domain of software usability are graphically presented. We observed that in 2013 and 2015, more studies were published with 12 and 9 studies, which are the most active years in the research domain. 2019 was also moderately active, with 7 studies. In general, even though the number of studies is linear, the research output continues to stabilize with stable yearly publication.

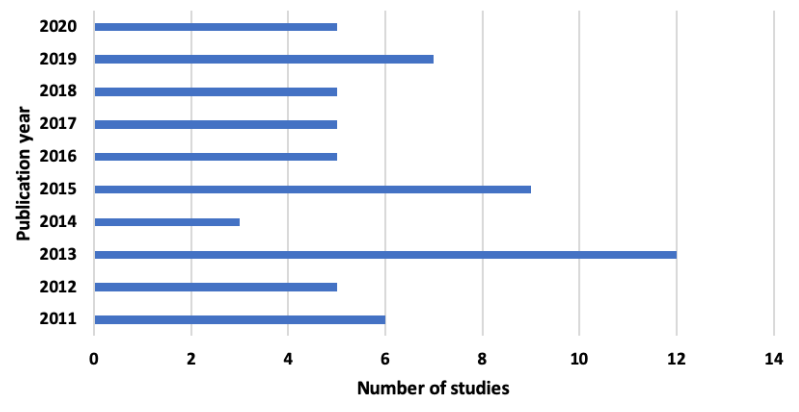

Fig. 2. Publication Trend Per Year.

Publication forums: This SMS study covered 20 different journals, 19 different conference proceedings, and 1 symposium and workshop each, respectively (see Appendix B). 39 papers are published in journals, 21 in conferences and one study each in workshop and symposium. From the analysis, we found that the International Journal of HumanComputer Interaction and the International Journal of HumanComputer Studies were the venues that contribute the most with 7 and 6 publications respectively followed by Journal of Systems and Software and Behavior and Information Technology with 4 and 2 publications each.

Citation impact: In Table V, the number of citations for the top 10 most cited papers is presented. We obtained the citation count of each paper from Google Scholar. Hence, the citation count may or will change at any point in time. In general, from our PS, we found four papers that have more than 100 citations each, which are Lee and Kozar [39], Kortum and Sorber [40], Mirkovic, et al. [41], and Maitama, et al. [36]. The total number of citations from the PS was 1809 as presented in Table IV. Therefore, the average number of citations per paper is 29.17 .

\section{B. RQ2. What Contribution Facets have the PS Provided?}

To answer the RQ, we conducted a thorough analysis of the selected PS. Based on the analysis, we found 13 key contributions. These contributions are summarized in Fig. 3. The most significant contributions are Investigation (23 papers), Evaluation (18 papers), and Model (8 papers). $37 \%$ of the PS conducted an investigative study on software usability, followed by evaluation (29\%), and model (13\%), respectively. The rest of the contributions have less than 5\% coverage. From our analysis, we observed that majority of the studies conducted an investigation into usability of existing web applications (B6, B15, B8, B38) or usability evaluation models (B37, B57, B53). Other studies focused more on proposing new models to help in facilitating or understanding key factors that facilitate or hinder usability of software or web application.
TABLE V. TOP CITED PAPERS

\begin{tabular}{|c|c|c|c|}
\hline $\begin{array}{l}\text { PS } \\
\text { Paper } \\
\text { ID }\end{array}$ & Paper Title & Citation & Year \\
\hline B21 & $\begin{array}{l}\text { Understanding of website usability: } \\
\text { Specifying and measuring constructs and } \\
\text { their relationships }\end{array}$ & 284 & 2012 \\
\hline B46 & $\begin{array}{l}\text { Measuring the usability of mobile } \\
\text { applications for phones and tablets }\end{array}$ & 118 & 2015 \\
\hline B32 & $\begin{array}{l}\text { Supporting cancer patients in illness } \\
\text { management: usability evaluation of a } \\
\text { mobile app }\end{array}$ & 113 & 2014 \\
\hline B31 & $\begin{array}{l}\text { Usability evaluation of mobile applications } \\
\text { using ISO } 9241 \text { and ISO } 25062 \text { standards }\end{array}$ & 103 & 2016 \\
\hline B18 & $\begin{array}{l}\text { Reliability, validity, and sensitivity of a } \\
\text { single-item measure of online store usability }\end{array}$ & 92 & 2011 \\
\hline B49 & $\begin{array}{l}\text { A comparison of usability evaluation } \\
\text { methods for evaluating e-commerce } \\
\text { websites }\end{array}$ & 83 & 2012 \\
\hline B19 & $\begin{array}{l}\text { Usability principles for augmented reality } \\
\text { applications in a smartphone environment }\end{array}$ & 78 & 2013 \\
\hline B22 & Usability through software design & 78 & 2013 \\
\hline B23 & $\begin{array}{l}\text { Aesthetics and usability of in-vehicle } \\
\text { navigation displays }\end{array}$ & 74 & 2011 \\
\hline B24 & $\begin{array}{l}\text { How do usability professionals construe } \\
\text { usability? }\end{array}$ & 75 & 2012 \\
\hline
\end{tabular}

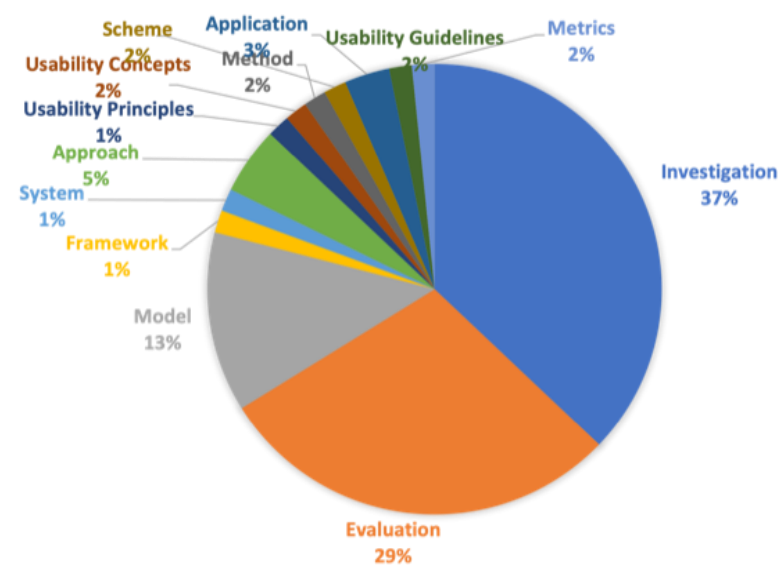

Fig. 3. Contributions by the Selected Studies.

Generally, we observed that a majority of the studies are not tailored to solution proposals, rather, they are focused on understanding software usability and ways to understand the factors that hinders users' acceptability and understandability of a software system. Despite the fact that software usability is not a recent research area, we observed that both investigative studies and evaluation studies are gaining attention from the researchers in this domain. This trend should be tailored into the proposition of new ways (in terms of framework, method, models, and so on) to help solve the usability issue in software engineering rather than just investigations and general evaluations. However, this is understandable because usability issues need to be understood using investigative and evaluation approaches. 


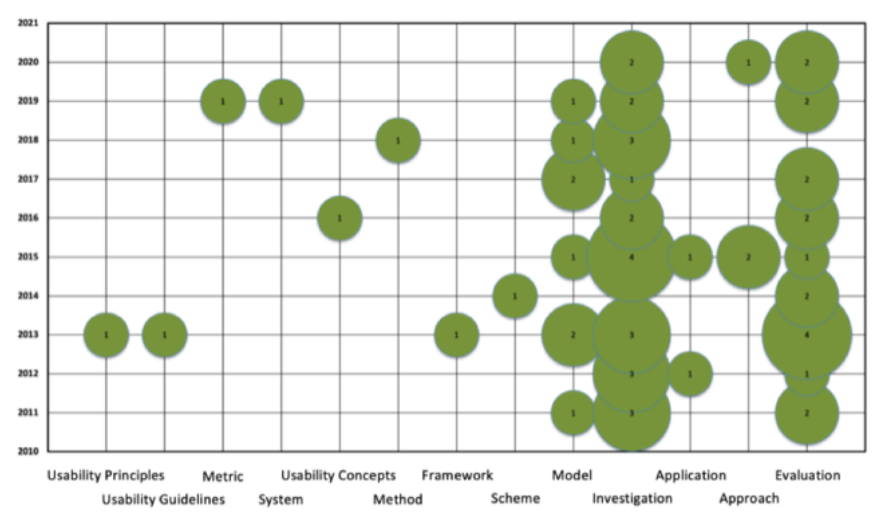

Fig. 4. Mapping of the Yearly Distribution of the Identified Contributions.

Fig. 4 shows the contributions on yearly basis. We observed that in 2018, no evaluation study was conducted. We further observed that from 2011 onward, research output is consistent and predictable. However, contributions such as framework, usability principles, usability guidelines, metric, system, usability concepts, method, scheme, and approach have received less attention in the field of study.

\section{RQ3. What are the Research Types (Facet) Focused by the} $P S$ in the Domain?

From the PS, we identified four key research facets. These research facets are experience paper, evaluation research, solution proposal, and validation research. Experience papers are intended to give an explanation of how issues are handled in practice. Hence, it is generally the personal experience of the authors conducting the work. An example of the experience paper is Komiyama, et al. [42] where the authors attempted to obtain the developers point of view on the usability of intensive software system. Solution proposal seeks to provide new and novel solutions to an established problem in a research domain. The example of a solution proposal is Diaz, et al. [43]. In their work, the authors proposed a new usability metrics for ecommerce website. Evaluation research is conducted to understand how a method is implemented in practice. An example of evaluation research is the work of Al-Maani and Salameh [44]. Validation research papers present a novel proposal that is not fully implemented in practice. Examples of validation research are Störrle [45], and Christophersen and Konradt [46].

From our analysis, as presented in Table VI, we found that most of the studies conducted Evaluation research with $33 \%$ of the PS. Furthermore, experience paper constitutes $29 \%$ of the total publications, followed by solution proposal with $24 \%$, and validation research with $13 \%$. The analysis shows that there is an urgent need for more solution proposals and research to validate the proposed proposals. Fig. 5 depicts the map for the identified research facets in correspondence to the validation methods. We observe that more experience papers are needed in this research domain to understand users' perspective with respect to usability issues.

\section{RQ4. What Validation Methods are Generally Utilized for} Software Usability Evaluation?

Validation methods are key to evaluating one's work in any scientific work. In answering this RQ, we identify eight validation methods utilized by the respective PS. These methods are experiment (22 studies), theoretical validation (10), case study (5), questionnaire (3), interview (3), interview and questionnaire (2), simulation (2), and field study (1). We observed that experiment and theoretical validation are the most used approaches by the PS in this domain. In Table VII, the identified validation methods with respect to the studies that used them are highlighted.

TABLE VI. RESEARCH FACETS

\begin{tabular}{|l|l|l|l|}
\hline Research Facet & Studies & No. of Studies & $\%$ \\
\hline \multirow{5}{*}{$\begin{array}{l}\text { Evaluation } \\
\text { Research }\end{array}$} & $\begin{array}{l}\text { B3, B40, B52, B54, B50, } \\
\text { B61, B57, B16, B44, B7, } \\
\text { B45, B32, B55, B2, B23, } \\
\text { B30, B31, B33, B38, B46, } \\
\text { B49 }\end{array}$ & 21 & \\
\hline \multirow{2}{*}{ Experience Paper } & $\begin{array}{l}\text { B5, B36, B41, B15, B43, } \\
\text { B58, B59, B4, B29, B9, } \\
\text { B24, B11, B14, B17, B20, } \\
\text { B34, B51, B62 }\end{array}$ & 18 & $33 \%$ \\
\hline Solution Proposal & $\begin{array}{l}\text { B6, B37, B48, B19, B42, } \\
\text { B26, B39, B53, B1, B12, } \\
\text { B13, B22, B47, B56, B60 }\end{array}$ & 15 & $29 \%$ \\
\hline $\begin{array}{l}\text { Validation } \\
\text { Research }\end{array}$ & $\begin{array}{l}\text { B10, B18, B21, B25, B27, } \\
\text { B28, B8, B35 }\end{array}$ & 8 & $24 \%$ \\
\hline
\end{tabular}

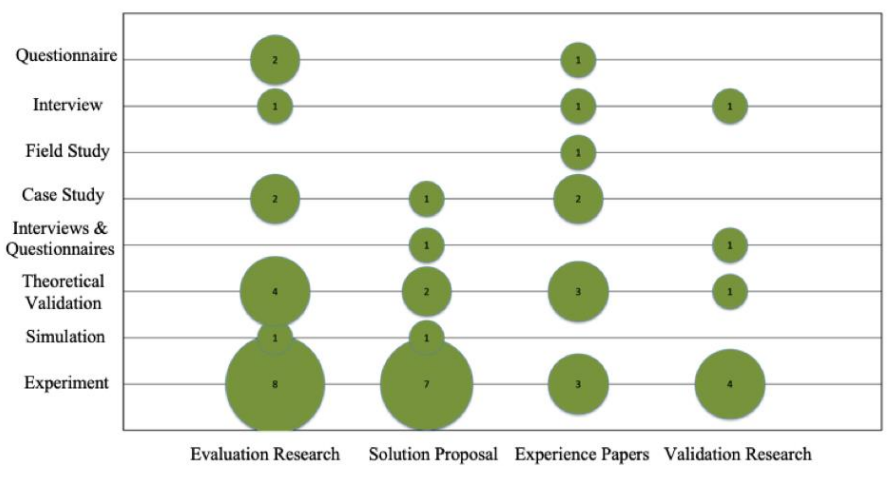

Fig. 5. Map for Research Facets against Validation Methods.

TABLE VII. VALIDATION METHODS

\begin{tabular}{|l|l|l|}
\hline Research Facet & Studies & No. of Studies \\
\hline Experiment & $\begin{array}{l}\text { B46, B22, B60, B1, B30, B31, B21, } \\
\text { B9, B10, B18, B29, B25, B56, B47, } \\
\text { B2, B33, B4, B23, B49, B12, B13, } \\
\text { B38 }\end{array}$ & 22 \\
\hline $\begin{array}{l}\text { Not clearly } \\
\text { defined }\end{array}$ & $\begin{array}{l}\text { B57, B53, B26, B35, B61, B50, } \\
\text { B51, B17, B11, B62, B34, B20, } \\
\text { B14, B39 }\end{array}$ & 14 \\
\hline $\begin{array}{l}\text { Theoretical } \\
\text { Validation }\end{array}$ & $\begin{array}{l}\text { B19, B42, B41, B36, B52, B3, B40, } \\
\text { B27, B5, B54 }\end{array}$ & 10 \\
\hline Case Study & B59, B45, B58, B37, B7 & 5 \\
\hline Questionnaire & B15, B44, B16 & 3 \\
\hline Interview & B24, B8, B32 & 3 \\
\hline $\begin{array}{l}\text { Interview and } \\
\text { Questionnaire }\end{array}$ & B6, B28 & 2 \\
\hline Simulation & B48, B55 & 2 \\
\hline Field Study & B43 & 1 \\
\hline
\end{tabular}




\section{E. RQ5. What are the Various Application Domains for Usability?}

In answering this RQ, we identified six application domains in the research area, which are web (17 studies), software development (16), mobile (8), industry and research (6), navigation (3), and robotics (1). We identified 11 studies that have no well-defined domain. Web is the most considered domain with $27 \%$ of the PS, followed by software development $(25 \%)$. Table VIII presents the application domains in the research area.

TABLE VIII. APPLICATION DOMAINS

\begin{tabular}{|l|l|l|}
\hline Application Domain & Studies & No. of Studies \\
\hline Web & $\begin{array}{l}\text { B6, B15, B8, B55, B37, B7, } \\
\text { B30, B21, B18, B29, B56, B2, } \\
\text { B49, B13, B38, B3, B61 }\end{array}$ & 17 \\
\hline $\begin{array}{l}\text { Software } \\
\text { Development }\end{array}$ & $\begin{array}{l}\text { B43, B44, B22, B60, B10, B42, } \\
\text { B41, B40, B27, B54, B53, B26, } \\
\text { B51, B11, B34, B14 }\end{array}$ & 16 \\
\hline $\begin{array}{l}\text { No Clear Domain } \\
\text { Identified }\end{array}$ & $\begin{array}{l}\text { B45, B58, B48, B24, B28, B12, } \\
\text { B36, B57, B35, B50, B62 }\end{array}$ & 11 \\
\hline Mobile & $\begin{array}{l}\text { B32, B46, B1, B31, B47, B33, } \\
\text { B19, B52 }\end{array}$ & 8 \\
\hline Industry \& Research & B16, B9, B4, B5, B17, B20 & 6 \\
\hline Navigation & B59, B25, B23 & 3 \\
\hline Robotics & B39 & 1 \\
\hline
\end{tabular}

F. RQ6. What are the Evaluation Measures used by the PS?

With respect to evaluation metrics, we observed that most of the studies (16) used usability as a metric. This is followed by effectiveness (4 studies) and learnability (4 studies). This research observed that some studies did not clearly identified the evaluation metric that were utilized by the research. This observation is quite alarming, because almost of the primary studies have no well-defined evaluation measures in their studies. Hence, this need to be address and more work need to clarify or use an evaluation metric for their study.

\section{DISCUSSION}

The discussion in this section comprises of two facets. Firstly, the main findings of the study are summarized and presented clearly. It is followed by highlighting areas in usability that have not received considerable attention from the researchers.

From 2011 - 2020, the research in software usability is generally stable. Most of the PS are published in journals (39), followed by conferences (21), workshop and symposium (1 each). We found that International Journal of HumanComputer Interaction and the International Journal of HumanComputer Studies are the venues that contributed the most with 7 and 6 publications, respectively. With respect to contribution facets, multiple key contributions were identified. $37 \%$ of the PS conducted an investigative study on software usability, followed by evaluation with $29 \%$ of the PS, and model with $13 \%$, respectively.

From our analysis, we observed that majority of the studies focused on usability testing of existing web applications (such as B6, B15, B8, B38) or usability evaluation models (such as B37, B57, B53). Other studies focused on proposing new models to help in understanding key factors that facilitate or hinder usability of software or web application. We observed that a majority of the studies are not tailored to solution proposals, rather, they are anchored in the direction of understanding software usability and ways to understand the factors that hinders users' acceptability and understandability of a software system.

From the PS, we identified four key research facets which are evaluation papers (33\%), experience papers (29\%), solution proposal (24\%), and validation research (13\%). We also identified eight validation methods utilized by the respective PS. These methods are experiment with 22 studies, followed by theoretical validation (10), case study (5), questionnaire (3), interview (3), interview and questionnaire (2), simulation (2), and field study (1). The research also identified three major evaluation metrics for evaluating proposals, which are used in this area. These metrics are usability, effectiveness and learnability. The proposals have been evaluated using a combination of metrics and sub-metrics as well. Some of the primary studies did not use any evaluation measure for validation. Hence, this needs to be addressed.

From our study, we observed that although a significant research is conducted to improve the usability of the software applications, there are still a number of research directions that needed to explore in more detail. For instance, when evaluating usability of software, majority of the works relied on closed experiments, questionnaires and surveys. It is recommended that future studies should focus more on field studies where an application usability is evaluated in real world conditions. Field studies are more beneficial as these are conducted by the end users in real operational environment resulting in identification of problems that might be overshadowed in laboratory-based tests. However, conducting the field-based study can be expensive both in terms of time and monetary value. An important aspect of software testing is the reproducibility of the errors/bugs. It is important to consider reproducibility of usability testing as a dimension in usability metrics.

Usability testing are used in a variety of domain such as aviation [47, 48], banking [49], bioinformatics [20] and medicine [28]. One area that is neglected by the researcher is the usability of software used by the scientific community. Most of the software applications developed for the use of scientific community are either command line or has poor user interfaces and faces numerous usability challenges. It will be important to consider usability testing of the scientific software and design a set of standard guidelines.

Ethics is an important aspect of software engineering process [50], however ethics in usability testing has received the least consideration by the researcher. It will be of interest to examine compliance of various ethical guidelines in usability testing. The ethical dimension of the usability testing is more important when considering the applications in domains such as health and finance.

Although considerable efforts are devoted in the literature to investigate the usability of mobile applications, we could not find any studies that focused on the cross-platform usability of 
various mobile applications. Generally, mobile applications are developed for different platforms (notably android and iOS). It will be helpful to investigate how the usability of mobile applications varies across different platforms.

In the recent past machine learning applications have seen widespread use in various domains $[51,52]$. However, there is limited work to evaluate the usability aspect of machine learning applications [53]. As the machine learning applications are adopted for more widespread use, it is recommended to conduct usability testing of these applications. Although, open source software has gained traction and acceptance, there is little work to assess the usability of such systems [54]. It will be important to assess the usability of open source software systems.

\section{THREAT TO VALIDITY}

After the rigorous analysis of the primary studies, this section discusses some identified issues that can be regarded as threat to validity. These limitations are discussed as follows.

Selection bias can be regarded as an external threat to the validity of our study. With respect to selection bias, even though the selected data sources were thoroughly searched by the author, there is a possibility that some important studies might be missed. To reduce this bias, this study employs inclusion and exclusion criteria for the selection of quality papers. The study is conducted by a single author which might result in selection bias. In order to mitigate the effect of the personal selection bias, two volunteer researchers oversaw the process and provided the feedback on the selection of final research papers for the study. Therefore, the threat level of personal selection bias is mitigated.

Conclusion validity is minimized by drawing all the relationships and conclusions from the literature based on the search query and then analyzing them using statistics such as citation count, classification into various sub-fields etc. Publication bias was mitigated by searching six important data sources. We also employed forward and backward snowballing techniques to make sure that all relevant studies related to software usability is identified, properly vetted and considered.

With respect to misclassification, some primary studies showed a limited information. Hence, some information was inferred while other where classified as "Nil" during the classification process. Hence, the inadequacy of information during classification may result in bias. In such a situation, the general methodology of a given study is carefully considered including the experimental setup to infer other classification entities. Therefore, this threat is mitigated to a certain level.

The selection of keywords can be regarded as threat of construct validity. We selected generalized keywords to identify a larger set of research papers in our domain from the various databases. Although it helped in reducing the probability of missing a relevant article, it has resulted in a large number of hits. In order to ensure that only relevant papers are selected for the study, a careful approach involving two volunteers as well as a carefully crafted approach is employed ensuring selection of relevant papers for the study.
Finally, the data was retrieved from the six selected data sources from 19 November 2020 to 25 December 2020. Therefore, if the same search query is executed at any later stage, different results might be obtained. Likewise, the citation count can be different as well as the research articles might have accrued more citations since 25th December 2020.

\section{CONCLUSION}

This work presented a mapping study that analyzed research work from 2011 to 2020 in the domain of software usability. From an initial pool of 9,874 papers, 62 papers were carefully selected based on our inclusion/exclusion criterion. This study examined the existing contributions, research facets, evaluation measures, validation methods, application domains, demographics, publication trends, and publication forums in the research domain. With respect to contributions, investigative studies and evaluation studies are the two most common approaches. We identified four key research facets, which are experience paper, solution proposal, evaluation research, and validation research. We also identified eight validation methods utilized by the respective PS. Usability, effectiveness and learnability are found to be the common evaluation metrics. Rather alarmingly, some of the primary studies have no clear evaluation metrics defined. Hence, this need to be address and more work need to clarify or use an evaluation metric for their study.

In conclusion, the aim of this mapping study was to allow researchers and experts to have a clear understanding of the general research productivity, trends and demographics that shaped the research domain of software usability. This work will help in highlighting potential opportunities for both new and experienced researchers to conduct more works with the aim of improving the research domain.

\section{REFERENCES}

[1] D. Gupta, A. K. Ahlawat, A. Sharma, and J. J. P. C. Rodrigues, "Feature selection and evaluation for software usability model using modified moth-flame optimization," Computing, vol. 102, pp. 1503-1520, 2020/06/01 2020. https://doi.org/10.1007/s00607-020-00809-6.

[2] K. Curcio, R. Santana, S. Reinehr, and A. Malucelli, "Usability in agile software development: A tertiary study," Computer Standards \& Interfaces, vol. 64, pp. 61-77, 2019/05/01/ 2019. https://doi.org/10.1016/j.csi.2018.12.003.

[3] K. Sagar and A. Saha, "A systematic review of software usability studies," International Journal of Information Technology, 2017/12/11 2017. https://doi.org/10.1007/s41870-017-0048-1.

[4] T. Alahmadi and S. Drew, "Subjective Evaluation of Website Accessibility and Usability: A Survey for People with Sensory Disabilities," presented at the Proceedings of the 14th International Web for All Conference, Perth, Western Australia, Australia, 2017. https://doi.org/10.1145/3058555.3058579.

[5] B. Aryana and T. Clemmensen, "Mobile Usability: Experiences From Iran and Turkey," International Journal of Human-Computer Interaction, vol. 29, pp. 220-242, 2013/03/01 2013. 10.1080/10447318.2013.765760.

[6] A. D. Nuovo, S. Varrasi, D. Conti, J. Bamsforth, A. Lucas, A. Soranzo, et al., "Usability Evaluation of a Robotic System for Cognitive Testing," in 2019 14th ACM/IEEE International Conference on Human-Robot Interaction (HRI), Daegu, Korea (South), 2019, pp. 588-589. https://doi.org/10.1109/HRI.2019.8673187.

[7] I. ISO, "Information technology-software product evaluation-quality characteristics and guide lines for their use," Iso/iec is, vol. 9126, 1991. 
[8] K. Bershinsky and R. Narciso, "An Experimental Framework for Determining the Usability of Mixed Reality Interfaces for Aerospace Applications," in AIAA Scitech 2019 Forum, ed. https://doi.org/10.2514/6.2019-0064.

[9] O. V. Bitkina, H. K. Kim, and J. Park, "Usability and user experience of medical devices: An overview of the current state, analysis methodologies, and future challenges," International Journal of Industrial Ergonomics, vol. 76, p. 102932, 2020/03/01/ 2020. https://doi.org/10.1016/j.ergon.2020.102932.

[10] M. A. Razzak and M. N. Islam, "Exploring and Evaluating the Usability Factors for Military Application: A Road Map for HCI in Military Applications," Human Factors and Mechanical Engineering for Defense and Safety, vol. 4, p. 4, 2020/01/10 2020. https://doi.org/10.1007/s41314-019-0032-6.

[11] H. M. Az-zahra, N. Fauzi, and A. P. Kharisma, "Evaluating Emarketplace Mobile Application Based on People At the Center of Mobile Application Development (PACMAD) Usability Model," in 2019 International Conference on Sustainable Information Engineering and Technology (SIET), Lombok, Indonesia, 2019, pp. 72-77. https://doi.org/10.1109/SIET48054.2019.8986067.

[12] R. P. Bringula, "Factors Affecting Web Portal Information Services Usability: A Canonical Correlation Analysis," International Journal of Human-Computer Interaction, vol. 32, pp. 814-826, 2016/10/02 2016. https://doi.org/10.1080/10447318.2016.1199180.

[13] M. Bures, M. Macik, B. S. Ahmed, V. Rechtberger, and P. Slavik, "Testing the Usability and Accessibility of Smart TV Applications Using an Automated Model-Based Approach," IEEE Transactions on Consumer Electronics, vol. 66, pp. 134-143, 2020. https://doi.org/10.1109/TCE.2020.2986049.

[14] M. Hertzum and T. Clemmensen, "How do usability professionals construe usability?," International Journal of Human-Computer Studies, vol. 70, pp. 26-42, 2012/01/01/ 2012 https://doi.org/10.1016/j.ijhcs.2011.08.001.

[15] W. Isa, M. R. Suhami, N. I. Safie, and S. S. Semsudin, "Assessing the usability and accessibility of Malaysia e-government website," American Journal of Economics and Business Administration, vol. 3, pp. 40-46, 2011. https://doi.org/10.3844/ajebasp.2011.40.46.

[16] W. P. N. H. Pathirana and D. N. Wickramaarachchi, "Software usability improvements for Generation Z oriented software application," in 2019 International Research Conference on Smart Computing and Systems Engineering (SCSE), Colombo, Sri Lanka, 2019, pp. 151-157. https://doi.org/10.23919/SCSE.2019.8842779.

[17] M. V. Waardhuizen, J. McLean-Oliver, N. Perry, and J. Munko, "Explorations on Single Usability Metrics," presented at the Extended Abstracts of the 2019 CHI Conference on Human Factors in Computing Systems, Glasgow, Scotland Uk, 2019. https://doi.org/10.1145/3290607.3299062.

[18] G. J. Esmeria and R. R. Seva, "Web usability: a literature review," in DLSU Research Congress, Manila, Philippines, 2017.

[19] A. Linja, "Review of usability assessment tools and standards," Michigan Technological University, Applied Cognitive Science and Human Factors, Michigan Technological University2019.

[20] S. Mangul, L. S. Martin, E. Eskin, and R. Blekhman, "Improving the usability and archival stability of bioinformatics software," Genome Biology, vol. 20, p. 47, 2019/02/27 2019. https://doi.org/10.1186/s13059-019-1649-8.

[21] M. Sure, "Questionnaires for usability: A systematic literature review," Independent thesis Advanced level (degree of Master (Two Years)), Department of Computer and Information Science, Human-Centered systems. , Linköping University, Linköping University, 2014.

[22] J. Nielsen, Usability engineering, 1st edition ed. Harcourt Place, 32 Jamestown Road, London, NW1 7BY, UK: Academic Press, Inc, 1993.

[23] N. Bevan, J. Carter, and S. Harker, "ISO 9241-11 Revised: What Have We Learnt About Usability Since 1998?," in 17th International Conference, HCI International, Los Angeles, CA, USA, 2015, pp. 143151. https://doi.org/10.1007/978-3-319-20901-2_13.

[24] J. M. Ferreira, S. T. Acuña, O. Dieste, S. Vegas, A. Santos, F. Rodríguez, et al., "Impact of usability mechanisms: An experiment on efficiency, effectiveness and user satisfaction," Information and
Software Technology, vol. 117, p. 106195, 2020/01/01/ 2020 https://doi.org/10.1016/j.infsof.2019.106195.

[25] R. Abiri, S. Borhani, J. Kilmarx, C. Esterwood, Y. Jiang, and X. Zhao, "A Usability Study of Low-Cost Wireless Brain-Computer Interface for Cursor Control Using Online Linear Model," IEEE Transactions on Human-Machine Systems, vol. 50, pp. 287-297, 2020. https://doi.org/10.1109/THMS.2020.2983848.

[26] F. P. Tulinayo, P. Ssentume, and R. Najjuma, "Digital technologies in resource constrained higher institutions of learning: a study on students' acceptance and usability," International Journal of Educational Technology in Higher Education, vol. 15, p. 36, 2018/09/27 2018. https://doi.org/10.1186/s41239-018-0117-y.

[27] J. M. C. Bastien, "Usability testing: a review of some methodological and technical aspects of the method," International Journal of Medical Informatics, vol. 79, pp. e18-e23, 2010/04/01/ 2010. https://doi.org/10.1016/j.ijmedinf.2008.12.004.

[28] I. Maramba, A. Chatterjee, and C. Newman, "Methods of usability testing in the development of eHealth applications: A scoping review," International Journal of Medical Informatics, vol. 126, pp. 95-104, 2019/06/01/ 2019. https://doi.org/10.1016/j.ijmedinf.2019.03.018.

[29] P. Weichbroth, "Usability of Mobile Applications: A Systematic Literature Study," IEEE Access, vol. 8, pp. 55563-55577, 2020. https://doi.org/10.1109/ACCESS.2020.2981892.

[30] C. K. Coursaris and D. J. Kim, "A meta-analytical review of empirical mobile usability studies," Journal of Usability Studies, vol. 6, pp. 117171, 2011.

[31] R. Harrison, D. Flood, and D. Duce, "Usability of mobile applications: literature review and rationale for a new usability model," Journal of Interaction Science, vol. 1, p. 1, 2013/05/07 2013. https://doi.org/10.1186/2194-0827-1-1.

[32] D. Quiñones and C. Rusu, "How to develop usability heuristics: A systematic literature review," Computer Standards \& Interfaces, vol. 53, pp. 89-122, 2017/08/01/ 2017. https://doi.org/10.1016/j.csi.2017.03.009.

[33] I. Ahmad, G. Ahmed, S. A. A. Shah, and E. Ahmed, "A decade of big data literature: analysis of trends in light of bibliometrics," The Journal of Supercomputing, vol. 76, pp. 3555-3571, 2020/05/01 2020. https://doi.org/10.1007/s11227-018-2714-x.

[34] K. Petersen, S. Vakkalanka, and L. Kuzniarz, "Guidelines for conducting systematic mapping studies in software engineering: An update," Information and Software Technology, vol. 64, pp. 1-18, 2015/08/01/ 2015. https://doi.org/10.1016/j.infsof.2015.03.007.

[35] B. Kitchenham and P. Brereton, "A systematic review of systematic review process research in software engineering," Information and Software Technology, vol. 55, pp. 2049-2075, 2013/12/01/ 2013. https://doi.org/10.1016/j.infsof.2013.07.010.

[36] J. Z. Maitama, N. Idris, and A. Zakari, "A Systematic Mapping Study of the Empirical Explicit Aspect Extractions in Sentiment Analysis," IEEE Access, $\quad$ vol. $\quad 8, \quad$ pp. $113878-113899,2020$. https://doi.org/10.1109/ACCESS.2020.3003625.

[37] S. Ouhbi, A. Idri, J. L. Fernández-Alemán, and A. Toval, "Requirements engineering education: a systematic mapping study," Requirements Engineering, vol. 20, pp. 119-138, 2015/06/01 2015. https://doi.org/10.1007/s00766-013-0192-5.

[38] A. Zakari, S. P. Lee, K. A. Alam, and R. Ahmad, "Software fault localisation: a systematic mapping study," IET Software, vol. 13, pp. 6074, 2019. https://doi.org/10.1049/iet-sen.2018.5137.

[39] Y. Lee and K. A. Kozar, "Understanding of website usability: Specifying and measuring constructs and their relationships," Decision Support Systems, vol. 52, pp. 450-463, 2012/01/01/ 2012. https://doi.org/10.1016/j.dss.2011.10.004.

[40] P. Kortum and M. Sorber, "Measuring the Usability of Mobile Applications for Phones and Tablets," International Journal of HumanComputer Interaction, vol. 31, pp. 518-529, 2015/08/03 2015. https://doi.org/10.1080/10447318.2015.1064658.

[41] J. Mirkovic, D. R. Kaufman, and C. M. Ruland, "Supporting Cancer Patients in Illness Management: Usability Evaluation of a Mobile App," JMIR Mhealth Uhealth, vol. 2, 2014. https://doi.org/10.2196/mhealth.3359. 
[42] T. Komiyama, S. i. Fukuzumi, M. Azuma, H. Washizaki, and N. Tsuda, "Usability of Software-Intensive Systems from Developers' Point of View," in 22nd HCII: International Conference on Human-Computer Interaction, Copenhagen, Denmark, 2020, pp. 450-463. https://doi.org/10.1007/978-3-030-49059-1_33.

[43] E. Diaz, S. Flores, and F. Paz, "Proposal of Usability Metrics to Evaluate E-commerce Websites," in 21st HCI International Conference on Design, User Experience, and Usability. Practice and Case Studies, Orlando, FL, USA, 2019, pp. 85-95. https://doi.org/10.1007/978-3-03023535-2_6.

[44] D. I. Al-Maani and H. B. Salameh, "A generic model for evaluating the usability of learning management systems," presented at the Proceedings of the Second International Conference on Internet of things, Data and Cloud Computing, Cambridge, United Kingdom, 2017. https://doi.org/10.1145/3018896.3018921.

[45] H. Störrle, "Improving model usability and utility by layered diagrams," presented at the Proceedings of the 10th International Workshop on Modelling in Software Engineering, Gothenburg, Sweden, 2018. https://doi.org/10.1145/3193954.3193958.

[46] T. Christophersen and U. Konradt, "Reliability, validity, and sensitivity of a single-item measure of online store usability," International Journal of Human-Computer Studies, vol. 69, pp. 269-280, 2011/04/01/ 2011. https://doi.org/10.1016/j.ijhcs.2010.10.005.

[47] J. McSorley, J. Kleber, and B. Blickensderfer, "Usability Analysis of Aviation Weather Products for General Aviation," Proceedings of the Human Factors and Ergonomics Society Annual Meeting, vol. 63, pp. 1903-1907, 2019/11/01 2019. https://doi.org/10.1177/107118131963 1339.
[48] H. Xue, T. Li, X. Zhang, and R. Wang, "Integrated Usability Evaluation Method for Cockpit of Civil Aircraft," in 17th International Conference on Man-Machine-Environment System Engineering, Jinggangshan, China, 2018, pp. 745-752. https://doi.org/10.1007/978-981-10-62322 289.

[49] I. Aboobucker and Y. Bao, "What obstruct customer acceptance of internet banking? Security and privacy, risk, trust and website usability and the role of moderators," The Journal of High Technology Management Research, vol. 29, pp. 109-123, 2018/01/01/ 2018. https://doi.org/10.1016/j.hitech.2018.04.010.

[50] I. Ozkaya, "Ethics Is a Software Design Concern," IEEE Software, vol. 36, pp. 4-8, 2019. https://doi.org/10.1109/MS.2019.2902592.

[51] I. Ahmad, M. A. Alqarni, A. A. Almazroi, and A. Tariq, "Experimental Evaluation of Clickbait Detection Using Machine Learning Models," Intelligent Automation And Soft Computing, vol. 26, pp. 1335-1344, 2020. https://doi.org/10.32604/iasc.2020.013861.

[52] I. Ahmad, M. Hamid, S. Yousaf, S. T. Shah, and M. O. Ahmad, "Optimizing Pretrained Convolutional Neural Networks for Tomato Leaf Disease Detection," Complexity, vol. 2020, p. 8812019, 2020/09/23 2020. https://doi.org/10.1155/2020/8812019.

[53] F. Bernardo, M. Zbyszyński, M. Grierson, and R. Fiebrink, "Designing and Evaluating the Usability of a Machine Learning API for Rapid Prototyping Music Technology," Frontiers in Artificial Intelligence, vol. 3, 2020-April-03 2020. https://doi.org/10.3389/frai.2020.00013.

[54] K. A. Dawood, K. Y. Sharif, A. A. Ghani, H. Zulzalil, A. A. Zaidan, and B. B. Zaidan, "Towards a unified criteria model for usability evaluation in the context of open source software based on a fuzzy Delphi method," Information and Software Technology, vol. 130, p. 106453, 2021/02/01/ 2021. https://doi.org/10.1016/j.infsof.2020.106453.

APPENDIX A. LIST OF PRIMARY STUDIES

\begin{tabular}{|c|c|}
\hline ID & Research Article Reference \\
\hline B1 & $\begin{array}{l}\text { Bures, M., Macik, M., Ahmed, B. S., Rechtberger, V., \& Slavik, P. (2020). Testing the usability and accessibility of smart tv applications using an } \\
\text { automated model-based approach. IEEE transactions on consumer electronics, 66(2), 134-143. }\end{array}$ \\
\hline B2 & $\begin{array}{l}\text { Alahmadi, T., \& Drew, S. (2017, April). Subjective evaluation of website accessibility and usability: A survey for people with sensory disabilities. } \\
\text { In Proceedings of the 14th International Web for All Conference (pp. 1-4). }\end{array}$ \\
\hline B3 & $\begin{array}{l}\text { D Al-Maani, D. I., \& Bani-Salameh, H. (2017, March). A generic model for evaluating the usability of learning management systems. In } \\
\text { Proceedings of the Second International Conference on Internet of things, Data and Cloud Computing (pp. 27-1). }\end{array}$ \\
\hline B4 & $\begin{array}{l}\text { Van Waardhuizen, M., McLean-Oliver, J., Perry, N., \& Munko, J. (2019, May). Explorations on Single Usability Metrics. In Extended Abstracts of } \\
\text { the } 2019 \text { CHI Conference on Human Factors in Computing Systems (pp. 1-8). }\end{array}$ \\
\hline B5 & $\begin{array}{l}\text { Komiyama, T., Fukuzumi, S. I., Azuma, M., Washizaki, H., \& Tsuda, N. (2020, July). Usability of Software-Intensive Systems from Developers' } \\
\text { Point of View. In International Conference on Human-Computer Interaction (pp. 450-463). }\end{array}$ \\
\hline B6 & $\begin{array}{l}\text { Diaz, E., Flores, S., \& Paz, F. (2019, July). Proposal of usability metrics to evaluate e-commerce websites. In International Conference on Human- } \\
\text { Computer Interaction (pp. 85-95). }\end{array}$ \\
\hline B7 & $\begin{array}{l}\text { Komarkova, J., Sedlak, P., Habrman, J., \& Cermakova, I. (2017, July). Usability evaluation of web-based GIS by means of a model. In } 2017 \\
\text { international conference on information and digital technologies (pp. 191-197). }\end{array}$ \\
\hline B8 & $\begin{array}{l}\text { Alotaibi, K. J. (2017, May). Gathering of usability requirements by Saudi e-learning software developers. In } 2017 \text { 8th International Conference on } \\
\text { Information Technology (pp. 255-261). }\end{array}$ \\
\hline B9 & $\begin{array}{l}\text { Okike, E. U., \& Morogosi, M. (2017, July). Measuring the usability probability of learning management software using logistic regression model. } \\
\text { In } 2017 \text { Computing Conference (pp. 1217-1223). }\end{array}$ \\
\hline B10 & $\begin{array}{l}\text { Störrle, H. (2018, May). Improving model usability and utility by layered diagrams. In Proceedings of the 10th International Workshop on } \\
\text { Modelling in Software Engineering (pp. 59-66). }\end{array}$ \\
\hline B11 & $\begin{array}{l}\text { Kwon, H., \& Choi, W. (2018, June). A Feld Study on Improving the API Usability of Software Platforms for Consumer Electronics Devices. In } \\
2018 \text { IEEE International Conference on Consumer Electronics-Asia (pp. 206-212). }\end{array}$ \\
\hline B12 & $\begin{array}{l}\text { Geszten, D., Hámornik, B. P., \& Hercegfi, K. (2018, August). Exploring awareness related usability problems of collaborative software with a } \\
\text { team usability testing approach. In } 2018 \text { 9th IEEE International Conference on Cognitive Infocommunications (pp. 45-50). }\end{array}$ \\
\hline B13 & $\begin{array}{l}\text { McClellan, M. A., Karumur, R. P., Vogel, R. I., Petzel, S. V., Cragg, J., Chan, D., .. \& Geller, M. A. (2016). Designing an educational website to } \\
\text { improve quality of supportive oncology care for women with ovarian cancer: an expert usability review and analysis. International journal of } \\
\text { human-computer interaction, 32(4), 297-307. }\end{array}$ \\
\hline B14 & $\begin{array}{l}\text { Lewis, J. R., Utesch, B. S., \& Maher, D. E. (2015). Measuring perceived usability: The SUS, UMUX-LITE, and AltUsability. International Journal } \\
\text { of Human-Computer Interaction, 31(8), 496-505. }\end{array}$ \\
\hline
\end{tabular}




\begin{tabular}{|c|c|}
\hline B15 & $\begin{array}{l}\text { Bringula, R. P. (2016). Factors affecting web portal information services usability: A canonical correlation analysis. International Journal of } \\
\text { Human-Computer Interaction, 32(10), 814-826. }\end{array}$ \\
\hline B16 & $\begin{array}{l}\text { Shamim, A., Balakrishnan, V., Tahir, M., \& Ahsan Qureshi, M. (2016). Age and domain specific usability analysis of opinion visualisation } \\
\text { techniques. Behaviour \& Information Technology, 35(8), 680-689. }\end{array}$ \\
\hline B17 & Hanrath, S., \& Kottman, M. (2015). Use and usability of a discovery tool in an academic library. Journal of web librarianship, 9(1), 1-21. \\
\hline B18 & $\begin{array}{l}\text { Christophersen, T., \& Konradt, U. (2011). Reliability, validity, and sensitivity of a single-item measure of online store usability. International } \\
\text { Journal of Human-Computer Studies, 69(4), 269-280. }\end{array}$ \\
\hline B19 & $\begin{array}{l}\text { Ko, S. M., Chang, W. S., \& Ji, Y. G. (2013). Usability principles for augmented reality applications in a smartphone environment. International } \\
\text { Journal of Human-Computer Interaction, 29(8), 501-515. }\end{array}$ \\
\hline B20 & $\begin{array}{l}\text { Leow, M. C., Wang, L. Y. K., Lau, S. H., \& Tan, C. K. (2016). Usability of rpg-based learning framework. International Journal of Human- } \\
\text { Computer Interaction, 32(8), 643-653. }\end{array}$ \\
\hline B21 & $\begin{array}{l}\text { Lee, Y., \& Kozar, K. A. (2012). Understanding of website usability: Specifying and measuring constructs and their relationships. Decision support } \\
\text { systems, 52(2), 450-463. }\end{array}$ \\
\hline B22 & $\begin{array}{l}\text { Carvajal, L., Moreno, A. M., Sanchez-Segura, M. I., \& Seffah, A. (2013). Usability through software design. IEEE Transactions on Software } \\
\text { Engineering, 39(11), 1582-1596. }\end{array}$ \\
\hline B23 & $\begin{array}{l}\text { Lavie, T., Oron-Gilad, T., \& Meyer, J. (2011). Aesthetics and usability of in-vehicle navigation displays. International Journal of Human- } \\
\text { Computer Studies, 69(1-2), 80-99. }\end{array}$ \\
\hline B24 & $\begin{array}{l}\text { Hertzum, M., \& Clemmensen, T. (2012). How do usability professionals construe usability?. International Journal of Human-Computer Studies, } \\
\text { 70(1), 26-42. }\end{array}$ \\
\hline B25 & $\begin{array}{l}\text { Roberts, M. J., Newton, E. J., Lagattolla, F. D., Hughes, S., \& Hasler, M. C. (2013). Objective versus subjective measures of Paris Metro map } \\
\text { usability: Investigating traditional octolinear versus all-curves schematics. International Journal of Human-Computer Studies, 71(3), 363-386. }\end{array}$ \\
\hline B26 & $\begin{array}{l}\text { Lallemand, C. (2011, June). Toward a closer integration of usability in software development: a study of usability inputs in a model-driven } \\
\text { engineering process. In Proceedings of the 3rd ACM SIGCHI symposium on Engineering interactive computing systems (pp. 299-302). }\end{array}$ \\
\hline B27 & $\begin{array}{l}\text { Baum, D., Bechert, S., Eisenecker, U., Meichsner, I., \& Müller, R. (2020, August). Identifying Usability Issues of Software Analytics Applications } \\
\text { in Immersive Augmented Reality. In } 2020 \text { Working Conference on Software Visualization (pp. 100-104). }\end{array}$ \\
\hline B28 & $\begin{array}{l}\text { Abiri, R., Borhani, S., Kilmarx, J., Esterwood, C., Jiang, Y., \& Zhao, X. (2020). A usability study of low-cost wireless brain-computer interface for } \\
\text { cursor control using online linear model. IEEE Transactions on Human-Machine Systems, 50(4), 287-297. }\end{array}$ \\
\hline B29 & $\begin{array}{l}\text { Isa, W. A. R. W. M., Suhami, M. R., Safie, N. I., \& Semsudin, S. S. (2011). Assessing the usability and accessibility of Mala ysia e-government } \\
\text { website. American Journal of Economics and Business Administration, 3(1), 40-46. }\end{array}$ \\
\hline B30 & $\begin{array}{l}\text { Rivero, L., \& Conte, T. (2013). Using an empirical study to evaluate the feasibility of a new usability inspection technique for paper based } \\
\text { prototypes of web applications. Journal of Software Engineering Research and Development, 1(1), 1-25. }\end{array}$ \\
\hline B31 & $\begin{array}{l}\text { Moumane, K., Idri, A., \& Abran, A. (2016). Usability evaluation of mobile applications using ISO } 9241 \text { and ISO } 25062 \text { standards. SpringerPlus, } \\
\text { 5(1), 1-15. }\end{array}$ \\
\hline B32 & $\begin{array}{l}\text { Mirkovic, J., Kaufman, D. R., \& Ruland, C. M. (2014). Supporting cancer patients in illness management: usability evaluation of a mobile app. } \\
\text { JMIR mHealth and uHealth, 2(3), e3359. }\end{array}$ \\
\hline B33 & $\begin{array}{l}\text { Az-zahra, H. M., Fauzi, N., \& Kharisma, A. P. (2019, September). Evaluating E-marketplace Mobile Application Based on People at the Center of } \\
\text { Mobile Application Development (PACMAD) Usability Model. In } 2019 \text { International Conference on Sustainable Information Engineering and } \\
\text { Technology (pp. 72-77). }\end{array}$ \\
\hline B34 & $\begin{array}{l}\text { Pathirana, W. P. N. H., \& Wickramaarachchi, D. N. (2019, March). Software usability improvements for Generation Z oriented software } \\
\text { application. In } 2019 \text { International research conference on smart computing and systems engineering (pp. 151-157). }\end{array}$ \\
\hline B35 & $\begin{array}{l}\text { Hamzah, N., Mageswaran, G., Nagappan, S. D., \& Chuprat, S. (2018, October). Assessing Usability of Ubiquitous Systems Using Quality Model. } \\
\text { In } 2018 \text { Fourth International Conference on Advances in Computing, Communication \& Automation (pp. 1 -4). }\end{array}$ \\
\hline B36 & $\begin{array}{l}\text { Tamimi, H., \& Bensefia, A. (2018, November). Software Usability Challenges for Native Arab Users. In } 2018 \text { 3rd International Conference on } \\
\text { System Reliability and Safety (pp. 6-12). }\end{array}$ \\
\hline B37 & $\begin{array}{l}\text { Abuqaddom, I., Alazzam, H., Hudaib, A., \& Al-Zaghoul, F. (2019, June). A measurable website usability model: Case Study University of Jordan. } \\
\text { In } 2019 \text { 10th International Conference on Information and Communication Systems (pp. 83-87). }\end{array}$ \\
\hline B38 & $\begin{array}{l}\text { Torrente, M. C. S., Prieto, A. B. M., Gutiérrez, D. A., \& De Sagastegui, M. E. A. (2013). Sirius: A heuristic-based framework for measuring web } \\
\text { usability adapted to the type of website. Journal of Systems and Software, 86(3), 649-663. }\end{array}$ \\
\hline B39 & $\begin{array}{l}\text { Di Nuovo, A., Varrasi, S., Conti, D., Bamsforth, J., Lucas, A., Soranzo, A., \& McNamara, J. (2019, March). Usability evaluation of a robotic } \\
\text { system for cognitive testing. In } 2019 \text { 14th ACM/IEEE International Conference on Human-Robot Interaction (pp. 588-589). }\end{array}$ \\
\hline B40 & $\begin{array}{l}\text { Vilbergsdottir, S. G., Hvannberg, E. T., \& Law, E. L. C. (2014). Assessing the reliability, validity and acceptance of a clas sification scheme of } \\
\text { usability problems (CUP). Journal of Systems and Software, 87, 18-37. }\end{array}$ \\
\hline B41 & $\begin{array}{l}\text { Wang, W., Cheng, J., \& Guo, J. L. (2020). How Do Open Source Software Contributors Perceive and Address Usability? Valued Factors, } \\
\text { Practices, and Challenges. IEEE Software. }\end{array}$ \\
\hline B42 & $\begin{array}{l}\text { Polgár, P. B. (2015). Using the cognitive walkthrough method in software process improvement. E-Informatica Software Engineering Journal, } \\
\text { 9(1). }\end{array}$ \\
\hline
\end{tabular}




\begin{tabular}{|c|c|}
\hline B43 & $\begin{array}{l}\text { Geszten, D., Hámornik, B. P., \& Hercegfi, K. (2019, October). Usability evaluation of a collaborative design software in the wild. In } 201910 \text { th } \\
\text { IEEE International Conference on Cognitive Infocommunications (pp. 101-106). }\end{array}$ \\
\hline B44 & $\begin{array}{l}\text { Teruel, M. A., Navarro, E., López-Jaquero, V., Montero, F., \& González, P. (2014). A CSCW requirements engineering CASE tool: development } \\
\text { and usability evaluation. Information and Software Technology, 56(8), 922-949. }\end{array}$ \\
\hline B45 & $\begin{array}{l}\text { Lindgaard, G. (2015). Challenges to assessing usability in the wild: a case study. International Journal of Human-Computer Interaction, 31(9), 618- } \\
631 .\end{array}$ \\
\hline B46 & $\begin{array}{l}\text { Kortum, P., \& Sorber, M. (2015). Measuring the usability of mobile applications for phones and tablets. International Journal of Human-Computer } \\
\text { Interaction, 31(8), 518-529. }\end{array}$ \\
\hline B47 & $\begin{array}{l}\text { Mansar, S. L., Jariwala, S., Shahzad, M., Anggraini, A., Behih, N., \& AlZeyara, A. (2012). A usability testing experiment for a localized weight } \\
\text { loss mobile application. Procedia Technology, 5, 839-848. }\end{array}$ \\
\hline B48 & $\begin{array}{l}\text { Hurtado, N., Ruiz, M., Orta, E., \& Torres, J. (2015). Using simulation to aid decision making in managing the usability evaluation process. } \\
\text { Information and Software Technology, 57, 509-526. }\end{array}$ \\
\hline B49 & $\begin{array}{l}\text { Hasan, L., Morris, A., \& Probets, S. (2012). A comparison of usability evaluation methods for evaluating e-commerce websites. Behaviour \& } \\
\text { Information Technology, 31(7), 707-737. }\end{array}$ \\
\hline B50 & $\begin{array}{l}\text { Hua, L., \& Gong, Y. (2013, July). Usability evaluation of a voluntary patient safety reporting system: Understanding the difference between } \\
\text { predicted and observed time values by retrospective think-aloud protocols. In International Conference on Human-Computer Interaction (pp. } 94- \\
\text { 100). Springer, Berlin, Heidelberg. }\end{array}$ \\
\hline B51 & $\begin{array}{l}\text { Bruun, A., \& Stage, J. (2012, November). Training software development practitioners in usability testing: an assessment acceptance and } \\
\text { prioritization. In Proceedings of the 24th Australian Computer-Human Interaction Conference (pp. 52-60). }\end{array}$ \\
\hline B52 & $\begin{array}{l}\text { Aryana, B., \& Clemmensen, T. (2013). Mobile usability: experiences from Iran and Turkey. International Journal of Human-Computer Interaction, } \\
\text { 29(4), 220-242. }\end{array}$ \\
\hline B53 & $\begin{array}{l}\text { Moorthy, J. T. S., bin Ibrahim, S., \& Mahrin, M. N. R. (2013, December). Formulation of usability risk assessment model. In } 2013 \text { IEEE } \\
\text { Conference on Open Systems (pp. 168-173). }\end{array}$ \\
\hline B54 & $\begin{array}{l}\text { Dubey, S. K., \& Rana, A. (2011). Usability estimation of software system by using object-oriented metrics. ACM SIGSOFT Software Engineering } \\
\text { Notes, 36(2), 1-6. }\end{array}$ \\
\hline B55 & $\begin{array}{l}\text { Erickson, W., Trerise, S., Lee, C., VanLooy, S., Knowlton, S., \& Bruyère, S. (2013). The accessibility and usability of colle ge websites: Is your } \\
\text { website presenting barriers to potential students?. Community College Journal of Research and Practice, 37(11), 864-876. }\end{array}$ \\
\hline B56 & $\begin{array}{l}\text { Rodríguez, F. D., Acuña, S. T., \& Juristo, N. (2015). Design and programming patterns for implementing usability functionalities in web } \\
\text { applications. Journal of Systems and Software, 105, 107-124. }\end{array}$ \\
\hline B57 & $\begin{array}{l}\text { Mapayi, T., Olaniyan, O., Isamotu, N., \& Moses, O. (2013). Evaluating usability factors in different authentication methods using artificial neural } \\
\text { network. African Journal of Computing \& ICT, 6(1), 69-78. }\end{array}$ \\
\hline B58 & $\begin{array}{l}\text { Wale-Kolade, A. Y. (2015). Integrating usability work into a large inter-organisational agile development project: Tactics developed by usability } \\
\text { designers. Journal of systems and software, 100, 54-66. }\end{array}$ \\
\hline B59 & $\begin{array}{l}\text { Brown, M., Sharples, S., \& Harding, J. (2013). Introducing PEGI: A usability process for the practical evaluation of Geographic Information. } \\
\text { International journal of human-computer studies, 71(6), 668-678. }\end{array}$ \\
\hline B60 & $\begin{array}{l}\text { Panach, J. I., Juristo, N., Valverde, F., \& Pastor, O. (2015). A framework to identify primitives that represent usability within Model-Driven } \\
\text { Development methods. Information and Software Technology, 58, 338-354. }\end{array}$ \\
\hline B61 & $\begin{array}{l}\text { Castilla, D., Garcia-Palacios, A., Breton-Lopez, J., Miralles, I., Baños, R. M., Etchemendy, E., ... \& Botella, C. (2013). Process of design and } \\
\text { usability evaluation of a telepsychology web and virtual reality system for the elderly: Butler. International Journal of Human-Computer Studies, } \\
71(3), 350-362 .\end{array}$ \\
\hline B62 & $\begin{array}{l}\text { Winter, J., \& Hinley, M. (2011). Examining correlations in usability data to effectivize usability testing. E-Informatica Software Engineering } \\
\text { Journal, 5(1). }\end{array}$ \\
\hline
\end{tabular}

APPENDIX B. LIST OF JOURNALS AND PROCEEDINGS

\begin{tabular}{|l|l|}
\hline IEEE transactions on consumer electronics & Journal \\
\hline Proceedings of the 14th International Web for All Conference & Conference \\
\hline Proceedings of the Second International Conference on Internet of things, Data and Cloud Computing & Conference \\
\hline Conference on Human Factors in Computing Systems & Conference \\
\hline International Conference on Human-Computer Interaction & Conference \\
\hline International conference on information and digital technologies & Conference \\
\hline International Conference on Information Technology & Conference \\
\hline Computing Conference & Conference \\
\hline Proceedings of the 10th International Workshop on Modelling in Software Engineering & Workshop \\
\hline IEEE International Conference on Consumer Electronics-Asia & Conference \\
\hline 9th IEEE International Conference on Cognitive Infocommunications & Conference \\
\hline
\end{tabular}




\begin{tabular}{|c|c|}
\hline International journal of human-computer interaction & Journal \\
\hline Behaviour \& Information Technology & Journal \\
\hline Journal of web librarianship & Journal \\
\hline International Journal of Human-Computer Studies & Journal \\
\hline Decision support systems & Journal \\
\hline IEEE Transactions on Software Engineering & Journal \\
\hline Proceedings of the 3rd ACM SIGCHI symposium on Engineering interactive computing systems & Symposium \\
\hline 2020 Working Conference on Software Visualization & Conference \\
\hline IEEE Transactions on Human-Machine Systems & Journal \\
\hline American Journal of Economics and Business Administration & Journal \\
\hline Journal of Software Engineering Research and Development & Journal \\
\hline SpringerPlus & Journal \\
\hline JMIR mHealth and uHealth & Journal \\
\hline International Conference on Sustainable Information Engineering and Technology & Conference \\
\hline International research conference on smart computing and systems engineering & Conference \\
\hline Fourth International Conference on Advances in Computing, Communication \& Automation & Conference \\
\hline 3rd International Conference on System Reliability and Safety & Conference \\
\hline 10th International Conference on Information and Communication Systems & Conference \\
\hline Journal of Systems and Software & Journal \\
\hline 14th ACM/IEEE International Conference on Human-Robot Interaction & Conference \\
\hline IEEE Software & Journal \\
\hline E-Informatica Software Engineering Journal & Journal \\
\hline 10th IEEE International Conference on Cognitive Infocommunications & Conference \\
\hline Information and Software Technology & Journal \\
\hline Procedia Technology & Journal \\
\hline 24th Australian Computer-Human Interaction Conference & Conference \\
\hline 2013 IEEE Conference on Open Systems & Conference \\
\hline ACM SIGSOFT Software Engineering Notes & Journal \\
\hline Community College Journal of Research and Practice & Journal \\
\hline African Journal of Computing \& ICT & Journal \\
\hline
\end{tabular}

